УДК 342.565:347.91

DOI https://doi.org/10.32849/2663-5313/2020.2.13

Ольга Ювчиия,

аспірантка кафедри цивільного процесу

Начіонального університету «Одеська юридична академія»

\title{
ПРИНЦИПИ НЕЗАЛЕЖНОСТІ ТА БЕЗСТОРОННОСТІ СУДУ В ЦИВІЛЬНОМУ СУДОЧИНСТВІ УКРАЇНИ: ІСТОРІЯ ВИНИКНЕННЯ ТА СТАНОВЛЕННЯ
}

Поняття приниипів незалежності та безсторонності суду як галузевих засад цивільного судочинства має давню та тривалу історію, хоча не завжди воно наповнювалось сучасним змістом. Аналіз історї виникнення та тлумачення зазначених приниипів, а також відображення у правовій доктрині дає можливість проаналізувати тендениї їхнього розвитку та дослідити їхню сутність.

Дослідження історіографії приниипів незалежності та безсторонності суду також дозволить встановити витоки цих засад, шлях становлення та перспективи подальшого розвитку. Дослідження приниипів незалежності та безсторонності суду як галузевих засад иивільного судочинства все ще продовжується сучасними науковиями, а тому питання наукового стану розробки иих організаиійно-правових засад иивільного судочинства у правовій доктрині залишається актуальним.

Метою статті є дослідження становлення та розвитку принципів незалежності та безсторонності суду як галузевих засад у иивільному судочинстві.

Авторка доходить висновку, що у своїй еволюиї принципи незалежності та безсторонності суду як галузеві засади иивільного судочинства пройшли декілька етапів. Кожний етап характеризується притаманними йому рисами, які розкривають зміст і сутність ијх приниипів.

Встановлено, що законодавство про цивільне судочинство України тривалий час розвивалося під впливом законодавства царської Росії, а після революиї 1917 р. - Російської Радянської Федеративної Сочіалістичної Республіки і Радянського Союзу як федеративної держави.

Зауважено, хоча приниипи незалежності та безсторонності суду не знайшли свого прямого закріплення в новій редакиї Цивільного процесуального кодексу Украӥни, однак вони є складовими елементами принииу верховенства права.

Для вдосконалення принципів незалежності та безсторонності суду та їх неухильного дотримання в иивільному судочинстві потрібно відшукати дієві механізми стимулювання дотримання иих основоположних засад судової влади. I в иьому може допомогти досвід низки країн, де такі приниипи вже історично вкоренилися, без дотримання них неможливий доступ до правосуддя.

Ключові слова: правосуддя, судова влада, цивільне судочинство, принципи судової влади, засади цивільного судочинства, незалежність суддів, безсторонність суду.

Постановка проблеми. Поняття принципів незалежності та безсторонності суду як елементів права на справедливий суд має давню і тривалу історію, хоча не завжди воно наповнювалось сучасним змістом. Аналіз історії виникнення і тлумачення зазначених принципів, а також відображення у правовій доктрині дає можливість з'ясувати тенденції їх розвитку, дослідити їхню сутність.

Дослідження історіографії принципів незалежності та безсторонності суду також дозволить встановити витоки цих засад, шлях становлення та перспективи подальшого розвитку. Водночас варто зазначити, що дослідження принципів незалежності та безсторонності суду все ще продовжується сучасними науковцями, тому питання наукового стану розробки цих організаційно-правових засад як елемента права на справедливий суд у правовій доктрині залишається актуальним.

Питання незалежності та безсторонності судової влади досліджували такі вчені, як: С. Бондарчук, В. Городовенко, I. Гриценко, I. Жаровська, О. Захарова, В. Комаров, А. Олійник, В. Маляренко, М. Погорецький, С. Сливка, В. Терьохін, Е. Трегубов, Т. Цувіна, М. Штефан, С. Штогун та інші. Проте залишається актуальним дослідження принципів незалежності та безсторонності суду як галузевих засад цивільного судочинства. 
Метою статті є дослідження становлення та розвитку принципів незалежності та безсторонності суду як елементів права на справедливий суд у цивільному судочинстві.

Виклад основного матеріалу. Проведені в Україні реформи цивільного процесу мають свій історико-правовий контекст. Законодавство про цивільне судочинство України тривалий час розвивалося під впливом законодавства царської Росії, а після революції 1917 р. - Російської Радянської Федеративної Соціалістичної Республіки (далі - РРФСР) і Радянського Союзу як федеративної держави. Виникнення сучасного цивільного процесу в Україні пов'язують із судовою реформою 1864 р. Олександра II, яка внесла значні зміни в судоустрій і судочинство кріпосницької Росії [1, с. 13].

Основним нормативним актом, що регулював цивільне судочинство, став Статут цивільного судочинства 1864 р. Він сприйняв принципи кодифікації цивільного процесу у Франції і фактично грунтувався на Цивільному процесуальному кодексі Французької республіки 1806 р. Ст. 1 Статуту передбачала, що будь-який спір про право цивільне підлягає вирішенню судовою установою, він виходив із принципів винятковості судової влади, іï незалежності, єдиного і рівного для всіх суду. В Україні, поряд зі Статутом цивільного судочинства 1864 р., також діяв Австрійський статут цивільного судочинства 1895 р. Цей Статут поширювався на території Західної України аж до іï приєднання до Української Радянської Соціалістичної Республіки (далі - УРСР) у другій половині 40-х рр. ХХ ст. [2, с. 9-10].

З 1917 по 1921 рр. судове законодавство України розвивалось драматично. Судовий устрій тих часів мав фрагментарний характер, оскільки цей період відзначався швидкоплинністю політичних процесів, які унеможливлювали створення засад незалежності української державності, зокрема судової системи. Деякі особливості формування судової системи мали місце із приходом до влади П. Скоропадського. Після падіння Гетьманату й приходу до влади Директорії також постала проблема створення судового апарату.

Найбільший вплив на судову систему мала Лютнева революція, оскільки судовий устрій особливо розгорнувся в січні і на початку лютого 1918 р., тобто після проголошення в Україні радянської влади. Першим законом про суд в Україні була постанова Народного секретаріату від 4 січня 1918 р. про введення народного суду. Цією постановою скасовувалася буржуазна судова сис- тема: окружні суди, судові палати, усі судові установи, натомість утворено місцеві суди [3, c. 53].

Розвиток судової системи України та цивільного процесуального законодавства здійснювався в епоху перетворень, спрямованих на побудову радянського суду i радянського судочинства. Початок цього періоду $є$ знаковим та характерним ще й тому, що в цей час відбулася диференціація цивільної юрисдикції.

Але фундаментальним явищем у розвитку законодавства і цивільного процесу України став Цивільний процесуальний кодекс УРСР 1924 р., який проголошував принципи диспозитивності, рівності сторін перед судом і законом, рівноправності сторін у процесі, активності суду, що розглядав справу, змагальності, гласності, національної мови судочинства, усності, безпосередності, безперервності [4, с. 615].

11 вересня 1929 р. ухвалено Цивільний процесуальний кодекс (далі - ЦПК) УРСР. Він набув чинності 1 грудня 1929 р. Цей Кодекс не змінив форми існуючого цивільного судочинства, по суті змістовно та структурно дублюючи ЦПК 1924 р. [5, с. 148].

Наприкінці 50-х - на початку 60-х рр. XX ст. в Радянському Союзі і союзних республіках проводилися широкомасштабні законодавчі роботи. Їхнім результатом, зокрема, стало ухвалення Основ цивільного судочинства Союзу Радянських Соціалістичних Республік (далі - СРСР) і союзних республік. На їхній базі верховні ради союзних республік увхалювали цивільні процесуальні кодекси. Цивільний процесуальний кодекс УРСР ухвалений 18 липня 1963 р. і введений у дію з 1 січня 1964 р. Порівняно із ЦПК 1924 р. та 1929 р. ЦПК 1963 р. був значно досконалішим законодавчим актом як $з$ погляду юридичної техніки, так і щодо змісту його інститутів і окремих норм. ЦПК 1963 р. передбачав такі принципи цивільного процесу, як: здійснення правосуддя тільки судом (ст. 6); незалежність суддів (ст. 8); мова судочинства (ст. 9); гласність судового розгляду (ст. 10); законність судової діяльності (ст. 11); диспозитивність (ст. ст. 5, 103 та ін.); змагальність (ст. 30 та ін.) тощо. Принцип незалежності суддів і підкорення їх тільки законові закріплювався у ст. 8 ЦПК УРСР 1963 р., де зазначалося, що під час здійснення правосуддя в цивільних справах судді незалежні і підкоряються тільки законові. Судді вирішують цивільні справи на основі закону, в умовах, що виключають сторонній вплив на них [6]

$\mathrm{y}$ нашій державі створення незалежного суду розпочалось ухваленням Декларації про 
державний суверенітет України 16 липня 1990 р. Після здобуття Україною незалежності в українській правовій системі відбулися зміни, зокрема й ті, які безпосередньо або опосередковано пов'язані з розвитком цивільного процесуального законодавства. Вони здійснювалися відповідно до Концепції судово-правової реформи в Україні, затвердженої постановою Верховної Ради України від 28 квітня 1992 р. [7].

Серед чинників, що зумовили необхідність проведення судово-правової реформи й ухвалення цієї Концепції, зазначали недостатню соціально-економічну захищеність суддів, а також факти втручання в діяльність правосуддя. Головною метою судово-правової реформи і формування незалежної судової влади було визначено перебудову судової системи, створення нового законодавства удосконалення форм судочинства. У процесі реформи вбачалось за необхідне:

- шляхом ефективного розмежування повноважень гарантувати самостійність і незалежність судових органів від впливу законодавчої і виконавчої влади;

- створити систему законодавства про судоустрій, яке б забезпечило незалежність судової влади;

- гарантувати право громадянина на розгляд його справи компетентним, незалежним і неупередженим судом.

Концепція передбачала основні принципи судово-правової реформи, до яких, зокрема, було віднесено такі:

- створення такого судочинства, яке максимально гарантувало б право на судовий захист, рівність громадян перед законом створило б умови для дійсної змагальності та реалізації презумпції невинності;

- відповідність нормативних актів із питань діяльності судів і органів юстиціі вимогам міжнародних угод, ратифікованих Україною [7].

Вищенаведене свідчить, що законодавець, хоча і не зазанчав серед принципів засад незалежності та безсторонності суду, однак ставив за мету перебудову судової системи саме для формування незалежної судової влади.

У зв'язку з тим, що в цей період розроблялася нова Конституція України, процес здійснення судово-правової реформи в Україні мав не системний, а фрагментарний характер. Законодавець обмежився окремими поправками до Цивільного процесуального кодексу. У період з 1991 по 1996 рр. у ЦПК вносилися істотні зміни, які загалом свідчать про спроби модифікації цивільного процесу. Однією з новел була та, яка скасувала прокурорський нагляд у цивільному судочинстві. Так, Зако- ном України від 15 грудня 1992 р. була змінена ст. 13 ЦПК 1963 р. у зв'язку з тим, що функції прокурора в цивільному процесі як органу, який здійснював нагляд за судовою діяльністю на той час, не сумісні з незалежністю судової влади.

Безумовно, важливу роль у становленні й законодавчому закріпленні незалежності судової влади відіграло ухвалення Конституції України 28 червня 1996 р. Принцип незалежності суддів був закріплений в окремій статті Основного закону нашої держави. Так, ст. 126 Конституції України передбачала, що незалежність і недоторканість суддів гарантуються Конституцією і законами України. Вплив на суддів у будь-який спосіб заборонявся [8].

Найбільш концентрований вплив Конституції на цивільне процесуальне право і законодавство виражається в закріпленні в ній принципів правосуддя. Конституційне закріплення принципів правосуддя має надзвичайно велике значення, оскільки цим визначаються орієнтири розвитку цивільного процесуального законодавства, його застосування, конституційний обсяг правового регулювання в цій сфері.

Оцінка нововведень у цивільному процесуальному законодавстві до 2001 р. дозволяє зробити висновок, що це не привело до зміни конструкції цивільного процесу, оскільки його модель, як і раніше, була вираженням ідеї соціального цивільного судового процесу [1, с. 29].

Новий закон про судоустрій ухвалений лише 7 лютого 2002 р. Ст. 14 Закону України «Про судоустрій» [9] передбачала самостійність і незалежність суддів, зокрема те, що суди здійснюють правосуддя самостійно. Судді під час здійснення правосуддя незалежні від будь-якого впливу, нікому не підзвітні і підкоряються лише закону. Гарантії самостійності та незалежності суддів визначаються Конституцією України й іншими законами. Встановлювався обов'язок органів і посадових осіб державної влади, органів місцевого самоврядування, їх посадових осіб, громадян та їх об'єднань, а також юридичних осіб поважати незалежність суддів і не посягати на неї. Заборонялися втручання у здійснення правосуддя, вплив на суд або суддів у будь-який спосіб, за що встановлювалася кримінальна відповідальність. Цим Законом також закріплювалися гарантії забезпечення самостійності судів та незалежності суддів.

Подальша еволюція правового регулювання принципів незалежності та безсторонності суду ознаменувалася ухваленням 18 березня 2004 р. нового ЦПК України, який набрав чинності 1 січня 2005 р. [10]. 
Загалом цей Кодекс відрізнявся від попереднього не лише за змістом, новими інститутами, але й певною мірою концептуально, тобто моделлю та структурою цивільного судочинства. У гл. 1 «Основні положення» ЦПК 2004 р. закріплювалися принципи цивільного процесу, однак, на відміну від ЦПК 1963 р., окремої статті, присвяченої незалежності та безсторонності суду, у цьому Кодексі не було.

7 липня 2010 р. відбувся черговий етап судової реформи, у результаті чого ухвалений новий закон «Про судоустрій і статус суддів». У р. 1 цього Закону закріплювалися засади організації судової влади, а ст. 1 передбачала, що судова влада в Україні, відповідно до конституційних засад поділу влади, здійснюється незалежними та безсторонніми судами. У ст. 2 Закону України «Про судоустрій і статус суддів» зазначено, що суд, здійснюючи правосуддя на засадах верховенства права, гарантує кожному право на справедливий суд, а ст. 3 цього Закону передбачала, що судова система забезпечує доступність правосуддя для кожної особи в порядку, установленому Конституцією та законами України [11].

Необхідно зазначити, що ст. 6 Закону України «Про судоустрій і статус суддів» 2010 р., хоча і називалася «Самостійність судів», але по суті встановлювала вимоги щодо незалежності та безсторонності суду. Вона передбачала, зокрема, що суди, здійснюючи правосуддя, $є$ незалежними від будьякого незаконного впливу. Цією ж нормою було заборонено втручання у здійснення правосуддя, вплив на суддів у будь-який спосіб, вплив на безсторонність суду, передбачалася кримінальна відповідальність за такі дії. Також ст. 7 цього Закону містила норму, яка гарантувала кожному захист його прав, свобод i законних інтересів незалежним і безстороннім судом, утвореним відповідно до закону [11].

Черговим етапом судової реформи стало внесення змін до Конституції України 2 червня 2016 р. щодо правосуддя. Низку статей Конституції, зокрема ст. 126, яка містила положення щодо недоторканості та незалежності суддів, було викладено в новій редакції. Так, згідно із цією статтею, незалежність і недоторканність судді гарантуються Конституцією і законами України. Вплив на суддю в будь-який спосіб забороняється. Без згоди Вищої ради правосуддя суддю не може бути затримано або утримувано під вартою чи арештом до винесення обвинувального вироку судом, за винятком затримання судді під час або відразу ж після вчинення тяжкого або особливо тяжкого злочину.
Суддю не може бути притягнуто до відповідальності за ухвалене ним судове рішення, за винятком учинення злочину або дисциплінарного проступку. Суддя обіймає посаду безстроково. Цією ж статтею визначені підстави для звільнення судді та припинення його повноважень [12].

2 червня 2016 р. також увхалений новий Закон «Про судоустрій і статус суддів», у ст. 6 якого закріплювався принцип незалежності судів. Так, здійснюючи правосуддя, суди є незалежними від будь-якого незаконного впливу. Суди здійснюють правосуддя на основі Конституції та законів України, на засадах верховенства права.

Звернення до суду громадян, організацій чи посадових осіб, які, відповідно до закону, не є учасниками судового процесу, щодо розгляду конкретних справ судом не розглядаються, якщо інше не передбачено законом.

Втручання у здійснення правосуддя, вплив на суд або суддів у будь-який спосіб, неповага до суду чи суддів, збирання, зберігання, використання і поширення інформації усно, письмово або в інший спосіб із метою дискредитації суду або впливу на безсторонність суду, заклики до невиконання судових рішень забороняються і мають наслідком відповідальність, установлену законом. Органи державної влади й органи місцевого самоврядування, їх посадові особи повинні утримуватися від заяв і дій, що можуть підірвати незалежність судової влади [13].

Остання новелізація нині чинного ЦПК України 2004 р. відбулася 3 жовтня 2017 р. Законом України «Про внесення змін до Господарського процесуального кодексу України, Цивільного процесуального кодексу України, Кодексу адміністративного судочинства України та інших законодавчих актів» ЦПК України 2004 р. було викладено в новій редакції. Необхідно зазначити, що вперше в Цивільному процесуальному кодексі викладено в одній статті засади цивільного судочинства, зокрема, ст. 2 ЦПК України «Завдання та основні засади цивільного судочинства» налічує дванадцять принципів [14].

Варто звернути увагу на те, що, хоча принципи незалежності та безсторонності суду не були прямо закріплені в новій редакції ЦПК, але вони є складовими елементами принципу верховенства права. Так, Свропейська комісія за демократію через право в доповіді про верховенство права від 25-26 березня 2011 р. визначила обов'язкові елементи поняття «верховенство права», як-от: 1) законність; 2) юридична визначеність; 3) заборона свавілля; 4) доступ до правосуддя, представленого незалежними 
та безсторонніми судами; 5) дотримання прав людини; 6) заборона дискримінації та рівність перед законом [15]. Найвищу цінність міжнародні гарантії прав людини являють собою тоді, коли вони підлягають виконанню на внутрішньодержавному рівні.

\section{Висновки}

Виходячи з наведеного, можна стверджувати, що у своїй еволюції принципи незалежності табезсторонності суду як галузевізасади цивільного судочинства пройшли декілька етапів, серед яких доцільно виокремити:

1) зародження правового регулювання принципів незалежності та безсторонності суду (XIV ст. - 1924 р.);

2) становлення i розвиток правового регулювання принципів незалежності та безсторонності суду в радянському цивільному процесуальному законодавстві (1924-1963 рр.);

3) подальший розвиток засад незалежності та безсторонності суду в цивільному процесуальному законодавстві УРСР і України, характерною особливістю якого стала детальна правова регламентація сутності цих принципів (1963-2004 рр.);

4) новелізація правового регулювання принципів незалежності та безсторонності суду в цивільному судочинстві України (2004 р. - дотепер).

Для вдосконалення принципів незалежності та безсторонності суду і їх неухильного дотримання в цивільному судочинстві потрібно запроваджувати дієві механізми стимулювання дотримання цих основоположних засад судової влади. I в цьому може допомогти досвід низки країн, де такі принципи вже історично вкоренилися, без дотримання таких принципів неможливий доступ до правосуддя.

\section{Список використаних джерел:}

1. Комаров В. Цивільне процесуальне законодавство в динаміці розвитку та практиці Верховного Суду України. Харків : Право, 2012. 624 c.

2. Васьковский Е. Учебник гражданского процесса. Москва, 1914. 572 с.

3. Рум'янцев В. Судова система в Україні в період Української революції 1917-1921 рр. Про- блеми законності : республіканський міжвідомчий науковий збірник / відп. ред. В. Тацій. Харків : Нац. юрид. акад. України, 2009. Вип. 100. С. 53-62.

4. Рейхель М. Гражданский процессуальный кодекс УССР. Вестник советской юстииии. 1924. № 19 (29). С. 615-618.

5. Бабій Б., Таранов А., Терлецький В. Історія держави і права Української РСР. Київ : Наукова думка, 1967. Т. 1 : 1917-1937 pp. 674 с.

6. Цивільний процесуальний кодекс України від 18 липня 1963 р., втратив чинність 1 вересня 2005 p. URL: https://zakon.rada.gov.ua/laws/ show/1501-06 (дата звернення: 17.01.2020).

7. Про Концепцію судово-правової реформи : постанова Верховної Ради України від 28 квітня 1992 р. Відомості Верховної Ради України. 1992. № 30. Ст. 42.

8. Конституція України від 28 червня 1996 р. № 254к/96-ВР. Офіиійний вісник України. 2010. № $72 / 1$. С. 15.

9. Про судоустрій України : Закон України від 7 лютого 2002 р. № 3018, втратив чинність 3 серпня 2010 p. URL: https://zakon.rada.gov.ua/ laws/show/3018-14 (дата звернення: 17.01.2020).

10. Цивільний процесуальний кодекс України від 18 березня 2004 р. № 1618-IV. Дата оновлення: 19.10.2019. URL: https://zakon.rada.gov.ua/laws/ show/1618-15 (дата звернення: 17.01.2020).

11.Про судоустрій і статус суддів : Закон України від 7 липня 2010 р., втратив чинність. Відомості Верховної Ради України. 2010. № № 41-45. Ст. 529 .

12. Про внесення змін до Конституції України (щодо правосуддя) : Закон України від 2 червня 2016 р. Відомості Верховної Ради України. 2016. № 28. Ст. 532.

13. Про судоустрій і статус суддів : Закон України від 2 червня 2016 р. Відомості Верховної Ради Украйни. 2016. № 31. Ст. 545.

14. Про внесення змін до Господарського процесуального кодексу України, Цивільного процесуального кодексу України, Кодексу адміністративного судочинства України та інших законодавчих актів : Закон України від 3 жовтня 2017 р. Відомості Верховної Ради України. 2017. № 48. Ст. 436. (

15. Європейська комісія «За демократію через право» (Веніційська комісія). Верховенство права. URL: http://www.scourt.gov.ua/clients/ vsu/vsu.nsf/6b6c1e2e6ad3e2fcc225745c0034f4cc 229b826c8ac787dec2257d87004987c3/\$FILE/ CDL-AD(2011)003rev-ukr.pdf (дата звернення: 17.01.2020). 
The notion of the principles of independence and impartiality of the court as a sectoral basis of civil justice has a long and long history, although it has not always been filled with modern content. The analysis of the history of the interpretation and interpretation of these principles, as well as the reflection in the legal doctrine, make it possible to analyze the tendencies of their development and to explore their essence.

The study of the historiography of the principles of independence and impartiality of the court, among other things, will allow to establish the origins of these principles, the way of formation and the prospect of further development. The study of the principles of independence and impartiality of the court as a sectoral basis of civil justice is still continued by modern scientists, and therefore the question of the scientific state of the development of these organizational and legal grounds in civil proceedings.

The purpose of the article is to investigate the formation and development of the principles of independence and impartiality of the court as a sectoral basis in civil proceedings.

The author concludes that in its evolution the principles of independence and the impartiality of the court as the sectoral principles of civil justice have passed several stages. Each stage is characterized by its inherent features that reveal the content and essence of these principles.

It is established that the legislation on civil justice of Ukraine for a long time developed under the influence of the legislation of tsarist Russia, and after the revolution of 1917 - the Russian Soviet Federal Socialist Republic and the Soviet Union as a federal state.

Attention is drawn to the fact that the principles of independence and impartiality of the court have not been directly enshrined in the new wording of the Civil Procedure Code of Ukraine, but they are an integral part of the rule of law principle.

In order to improve the principles of independence and impartiality of the court and their steadfast adherence in civil proceedings, it is necessary to find effective mechanisms to encourage adherence to these fundamental principles of the judiciary. And this can be helped by the experience of a number of countries where such principles have been historically rooted and without which access to justice is impossible.

Key words: justice, judiciary, civil justice, principles of judiciary, principles of civil justice, independence of judges, impartiality of court. 